\title{
A compact machine for feeding sheep up to twelve times daily
}

\author{
By J. L. ClAPPERTON, P. C. THOMAS, M. R. STOKES \\ AND J. M. HENDERSON \\ The Hannah Research Institute, Ayr, Scotland, $\mathrm{KA}{ }_{5} \mathrm{HL}$ \\ (Received 9 August 1973-Accepted I2 September 1973)
}

\begin{abstract}
I. A machine is described which is small enough to fit into a respiration calorimeter and which enables sheep to be fed automatically up to twelve times daily.
\end{abstract}

When sheep fed at frequent intervals are compared with those given food only once or twice daily the composition of the digesta in the reticulo-rumen is much more constant throughout the day (Minson, I966; Ibrahim, Ingalls $\&$ Phillips, 1969), the rate of passage of digesta from the reticulo-rumen is more uniform although slower (Murray, Reid \& Sutherland, 1962) and the variability in the rate of excretion in the faeces is markedly reduced (Minson \& Cowper, 1966). Many machines have been designed to enable sheep to be offered food automatically at frequent intervals (Murray et al. I962; Beeston, I964; Minson \& Cowper, I966; Gray, Weller, Pilgrim \& Jones, 1967; Nicol \& Corbett, 1971), but most of the machines described by these authors are rather large with at least one dimension over $\mathrm{I} \cdot 5 \mathrm{~m}$. We wanted a machine which could be fitted into a respiration calorimeter (Wainman \& Blaxter, I958) with dimensions not exceeding $660 \mathrm{~mm}$ wide, $610 \mathrm{~mm}$ long and $910 \mathrm{~mm}$ high, including the chute to the feed trough. The total volume of the food troughs of the machine had to be about 251 to enable up to $1 \cdot 5 \mathrm{~kg}$ chopped hay to be fed daily. Under these conditions it was necessary to accept a limitation of twelve feeds $/ 24 \mathrm{~h}$, but if the machine were to be fitted on to a sheep metabolism cage and hence be readily accessible, twenty-four feeds $/ 24 \mathrm{~h}$ could be obtained by filling twice daily.

The general arrangement is shown in Pl. I. The troughs made by a local firm (Wallace McDowall Ltd, Ayr) from 22-gauge galvanized mild steel sheet, are $216 \mathrm{~mm}$ long, I $52 \mathrm{~mm}$ deep and $76 \mathrm{~mm}$ wide. Each trough is pivoted on a $9.5 \mathrm{~mm}$ bright-steel bar and supported by a plastic catch attached to a solenoid (Magnetic Devices Ltd, Newmarket, type no 67426) as shown in P1. 2. When the troughs are lifted by hand for refilling, the triggers are automatically reset. The solenoids are operated sequentially by a cam-timer (Magnetic Devices Ltd, type no $83012 \mathrm{~B}_{3} / 24 \mathrm{H} / 12 \mathrm{C} 6 \mathrm{~A} / 240$ ). Because the solenoids are not continuously rated, the supply to them is cut off for about $90 \%$ of a 4 min cycle by means of a cam-operated switch driven by a synchronous motor (Smith Industries Ltd, type QIM I 5 RMC). Although the animals are normally fed every $2 \mathrm{~h}$, other sequences may be obtained by arranging switches to make more than one solenoid operate together. The total cost of the materials used in building the first machine was approximately $£ 5^{\circ}$. Subsequent units should cost about $£ 40$ each. 


\section{REFERENCES}

Beeston, J. W. U. (1964). Proc. Aust. Soc. Anim. Prod. 5, 357.

Gray, F. V., Weller, R. A., Pilgrim, A. F. \& Jones, G. B. (Ig67). Aust. F. agric. Res. 18, 625.

Ibrahim, E. A., Ingalls, J. R. \& Phillips, G. D. (1969). Can. F. Anim. Sci. 49, 399.

Minson, D. J. (1966). Br. F. Nutr. 20, 765.

Minson, D. J. \& Cowper, J. L. (I966). Br. F. Nutr. 20, 757.

Murray, M. G., Reid, R. S. \& Sutherland, T. M. (1962). F. Physiol., Lond, 164, 26 P.

Nicol, G. R. \& Corbett, J. L. (1971). Lab. Pract. 20, 727.

Wainman, F. W. \& Blaxter, K. L. (1958). Publs Eur. Ass. Anim. Prod. no 8, p. 85.

\section{EXPLANATION OF PLATES}

Plate r. General arrangement of the machine for feeding sheep. The complete machine fits on top of a chute guiding the food into the feeding trough.

Plate 2. Solenoid and trigger arrangement in the sheep-feeding machine. The trigger is made of nylon and pivoted on a 4 BA nut and bolt. 
British fournal of Nutrition, Vol. 3 I, No. 2

Plate I

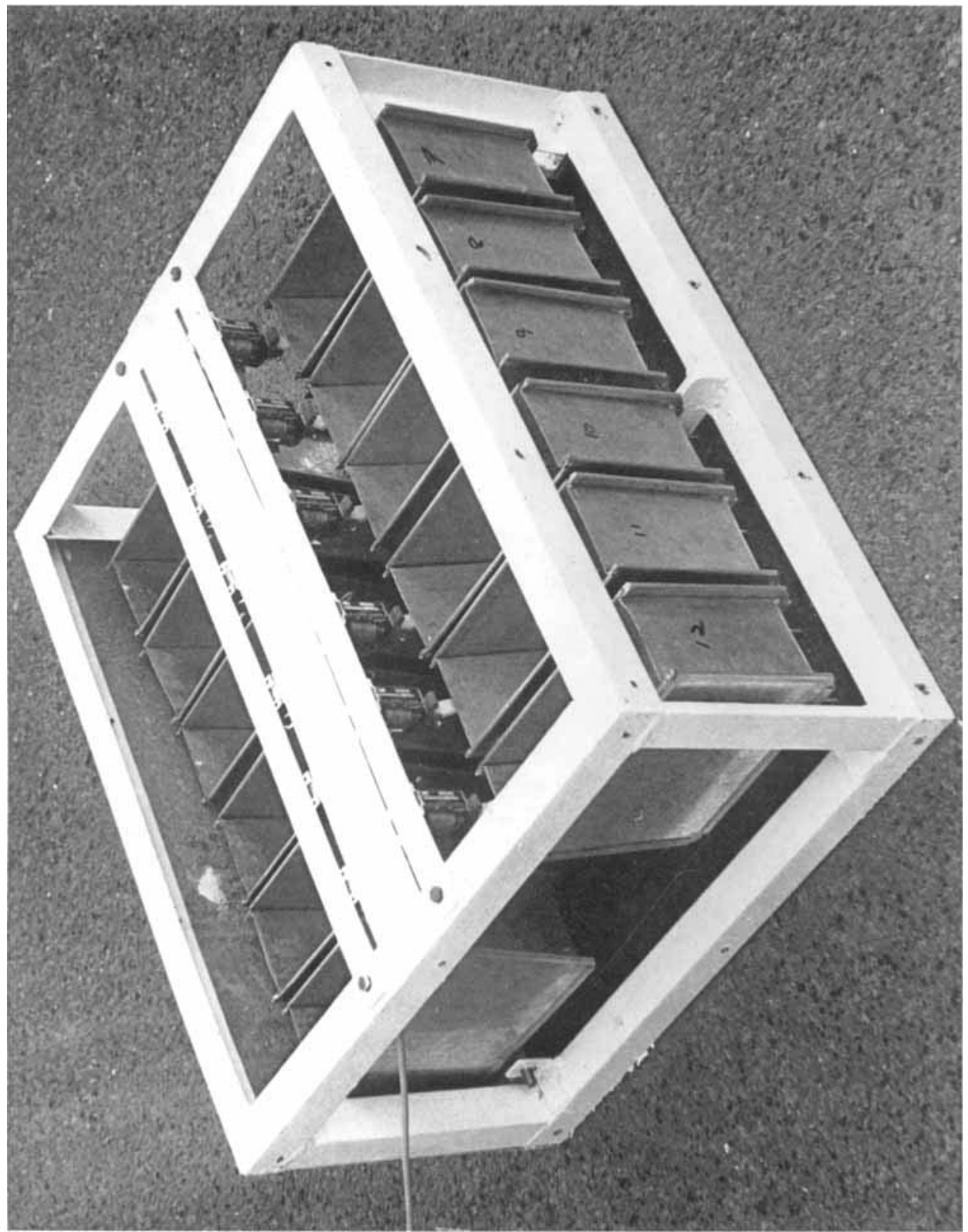


British Foumal of Nutrition, Vol. 31, No. 2

Plate 2

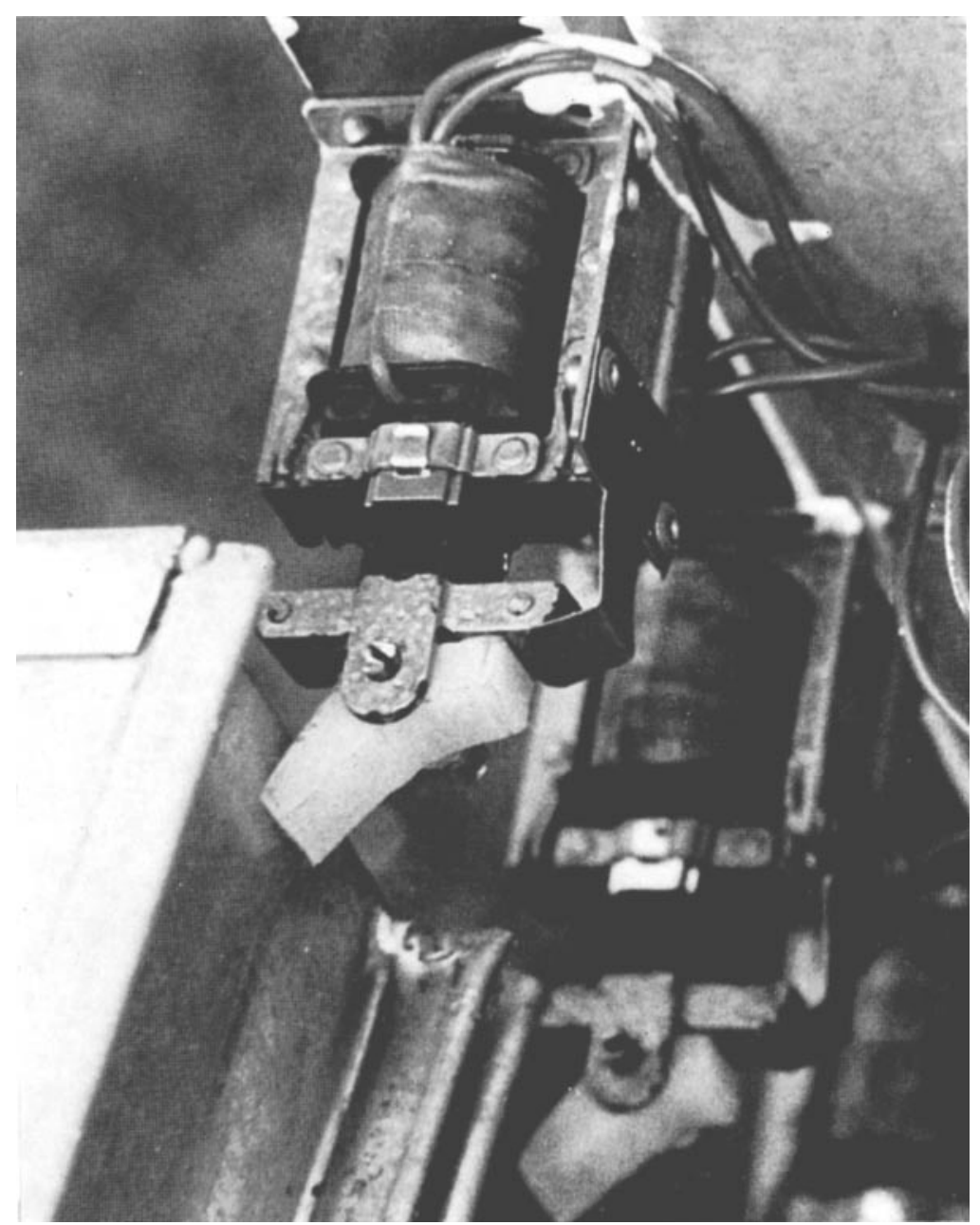

